\title{
Project approach in an anti-crisis management system of financial sustainability of industrial enterprise
}

\section{Svitlana Bondarenko ${ }^{\text {; }}$ Olena Makoveieva ${ }^{\text {B }}$; Anatolii Polishchuk ${ }^{\text {C }}$ Mykhailo Mosin ${ }^{\text {D }}$}

Received: April 11, 2020 | Revised: April 27, 2020 | Accepted: April 30, 2020

JEL Classification: D01, C51.

DOI: $10.33445 /$ sds.2020.10.2.10

\begin{abstract}
The main aspects of the project approach in the system of crisis management of financial stability of an industrial enterprise are considered in the article. Definitely main factors and signs of the crisis based on the diagnosis of indicators of the financial condition of the industrial enterprise. It is established that the assessment of financial stability is one of the priority tasks in the diagnosis of crisis enterprises, the condition of which is characterized by an increased probability of bankruptcy. The forecast value of the coefficient of financial stability, which can be used to develop a financial strategy of the enterprise or corrective anti-crisis management decisions, is determined. The article proposes a method of implementing a project approach in crisis management of the enterprise. In anti-crisis management of financial stability it is expedient to apply the project approach that will give the chance to implement measures for achievement of the concrete purpose, to coordinate actions of all divisions of the enterprise; to forecast in time and in expenses the project decision of a crisis situation according to the set criteria of quality of performance of works. In addition, the project approach has all the features of the crisis management system: a team of specialists is formed to perform the tasks of crisis management; strategies for increasing the competitiveness of the enterprise are developed; optimal ways (options) of realization of system of anti-crisis measures for the purpose of increase of stability of functioning of the enterprise are made. The advantages of the project approach in crisis management of financial stability are: assessment of the current state of the enterprise; use of the company's own resources in order to reduce the cost of implementing a system of anti-crisis measures; clear delineation and definition of personal (team) responsibilities and powers; systematic approaches to determining the phenomena and factors of the crisis, as well as to the development and implementation of anti-crisis programs, due to the involvement of specialists and managers of different levels and areas of activity, in accordance with the sources of threats; increasing control over the expenditure of funds and resources aimed at anti-crisis measures, the introduction of methods for their more effective use; more effective use of the time factor in the analysis of the situation and the implementation of anti-crisis measures; qualitative increase of the level of systems and methods of internal communications. The result of this approach should be overcoming the crisis (with the subsequent transition to operational management of the organization), assessing the effectiveness of crisis measures (actions, projects) and, if necessary, the introduction of a permanent monitoring system for crisis phenomena in the organization. introduction of methods of their more effective use; more effective use of the time factor in the analysis of the situation and the implementation of anti-crisis measures; qualitative increase of the level of
\end{abstract}

\footnotetext{
A The National Defence University of Ukraine named after Ivan Cherniakhovskyi, Kyiv, Ukraine, Doctor of Economics, Leading Researcher at the Defence Management Education and Training Center, e-mail: lana.bond@ukr.net, ORCID: 0000-0002-1687-1172

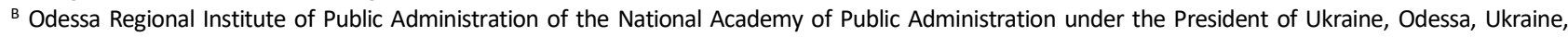
Associate professor at the Organizations Management Department, e-mail: makoveeva.e@ukr.net, ORCID: 0000-0003-2726-915X

${ }^{c}$ National Technical University of Ukraine, Kyiv Polytechnic Institute named after Igor Sikorsky, Kyiv, Ukraine, PhD student of the Department of International Economics, e-mail: avalonanatoly@gmail.com, ORCID: 0000-0003-0558-6728

${ }^{D}$ National Technical University of Ukraine, Kyiv Polytechnic Institute named after Igor Sikorsky, Kyiv, Ukraine, PhD student of the Department of International Economics, e-mail: mosin-ussz@ukr.net
} 
systems and methods of internal communications. The result of this approach should be overcoming the crisis (with the subsequent transition to operational management of the organization), assessing the effectiveness of crisis measures (actions, projects) and, if necessary, the introduction of a permanent monitoring system for crisis phenomena in the organization. introduction of methods of their more effective use; more effective use of the time factor in the analysis of the situation and the implementation of anti-crisis measures; qualitative increase of the level of systems and methods of internal communications. The result of this approach should be overcoming the crisis (with the subsequent transition to operational management of the organization), assessing the effectiveness of crisis measures (actions, projects) and, if necessary, the introduction of a permanent monitoring system for crisis phenomena in the organization.

Key words: financial stability, anti-crisis management system of the enterprise, project approach, industrial enterprise.

\section{Introduction}

The basis of financial and economic stability of the enterprise is its solvency, financial stability, liquidity, profitability. Defining the limits of financial stability is one of the most pressing problems of enterprise management. This is especially important in a crisis, because the company becomes relevant to determine the reserves and opportunities to increase its own financial resources and their most rational use to improve the efficiency of the economic system as a whole.

As practice shows, the crisis is a unique situation, to overcome which a set of methods and actions is formed, taking into account the limited funds, resources and time. Achieving the strategic goals of the enterprise in a crisis requires optimization of management in general, in particular more active use of project management methods, which involves obtaining certain results at given parameters during the development and implementation of crisis strategies. All this determines the need to identify and study the specifics of anti-crisis projects and, accordingly, crisis project management to address the problem of effective management of financial stability of enterprises in a crisis.

When substantiating the methodology of the project approach in the system of crisis

\section{Material and methods}

This study considers the concepts of crisis, crisis management, project approach, financial stability. In the modern scientific literature, a crisis is defined as a process that can potentially have a management of financial stability of an industrial enterprise, it is important to identify the stages and typical features of the corporate crisis in the worst case scenario, i.e. when realizing the threat of financial insolvency. It is necessary to identify in which case the company is subject to bankruptcy proceedings and in the presence of which signs it is considered completely insolvent and liquidated. To do this, there are two areas of financial diagnosis of crisis enterprises: the assessment of signs of bankruptcy, in the presence of which requires external, primarily judicial, intervention in debt settlement, and assessment of the possibility of restoring financial stability in order to address the key issue of the feasibility of implementing a project approach for rehabilitation and further business continuation. The content of signs of bankruptcy of the enterprise from the standpoint of financial diagnostics is investigated. The research used methods of economic and statistical information processing, as well as systematic financial and economic analysis, methods of financial analysis and forecasting of corporate bankruptcy, including statistical and expert approaches to solving problems, the method of correlation and regression analysis.

successful outcome in the form of a return to the pre-crisis past and even be an incentive for renewal and development. The crisis is a serious threat to the core structures, core values or norms 
of the system, which forces to make a radical decision in a limited time and significant uncertainty (Patterson, 1993). The project approach should integrate into the existing management system of the enterprise, in accordance with the scope and scale of "anticrisis" tasks, and extend to all activities of the company and its individual areas (Roux-Dufort, 2005).

The main factors in the effectiveness of anticrisis measures are the timeliness of crisis identification, the level of adequacy of decisions and strategies (Rostow, 1960). In crisis conditions, the importance of certain areas of project management changes, so the main issues during the crisis are forecasting the situation, coordination of tactical anti-crisis actions with strategic goals, dynamic strategy management and effective monitoring of the situation (Bondarenko, 2018; Buzzel, 1993; Patterson, 1993). The International Project Management Body of Knowledge standard indicates the need to identify in advance the main points of the organizational structure of the enterprise, human resources, market situation, risk readiness and the state of resources for project implementation. Before launching an anti-crisis project, it is necessary to make a decision on the appointment, training and retraining - based on the evaluation of managers for project management involved in the construction and implementation of crisis management system or the introduction of outsourcing (Burton, 2004). To get the company out of crisis, it is necessary to ensure its financial stability, which is characterized by financial independence from external debt sources, the ability of the company to maneuver financial resources, the availability of the necessary amount of own funds to provide basic activities (Mitroff, 1994). To do this, it is important to provide an objective assessment of financial stability, assess the financial condition of the enterprise in terms of real opportunities through rational resource management to create such an excess of income over costs, which achieves a stable cash flow that will allow the company to ensure its current and long-term solvency. meet the investment expectations of owners (Bondarenko, Nizyayeva, 2017).

Setting objectives. The purpose articles are available research project approach in the system of crisis management of financial stability of an industrial enterprise. In the framework of this study, the following problematic issues are identified: main factors and signs of the crisis based on the diagnosis of indicators of the financial condition of the industrial enterprise; methods of implementing a project approach in crisis management of the enterprise.

enterprise is characterized by the coefficients of capital structure (financial independence; financial stability), as well as the ratio of working capital to its own sources of financing. The coefficient of financial independence shows the degree of financial independence of the enterprise. The coefficient of financial stability reflects what part of the property is financed from sustainable sources (ie the share of those sources that the company can use for a long time). And finally, part of the current assets of the enterprise is financed from its own sources. The assessment of the financial stability indicator is supplemented by the assessment of the indicators of financial flexibility and financial potential. 


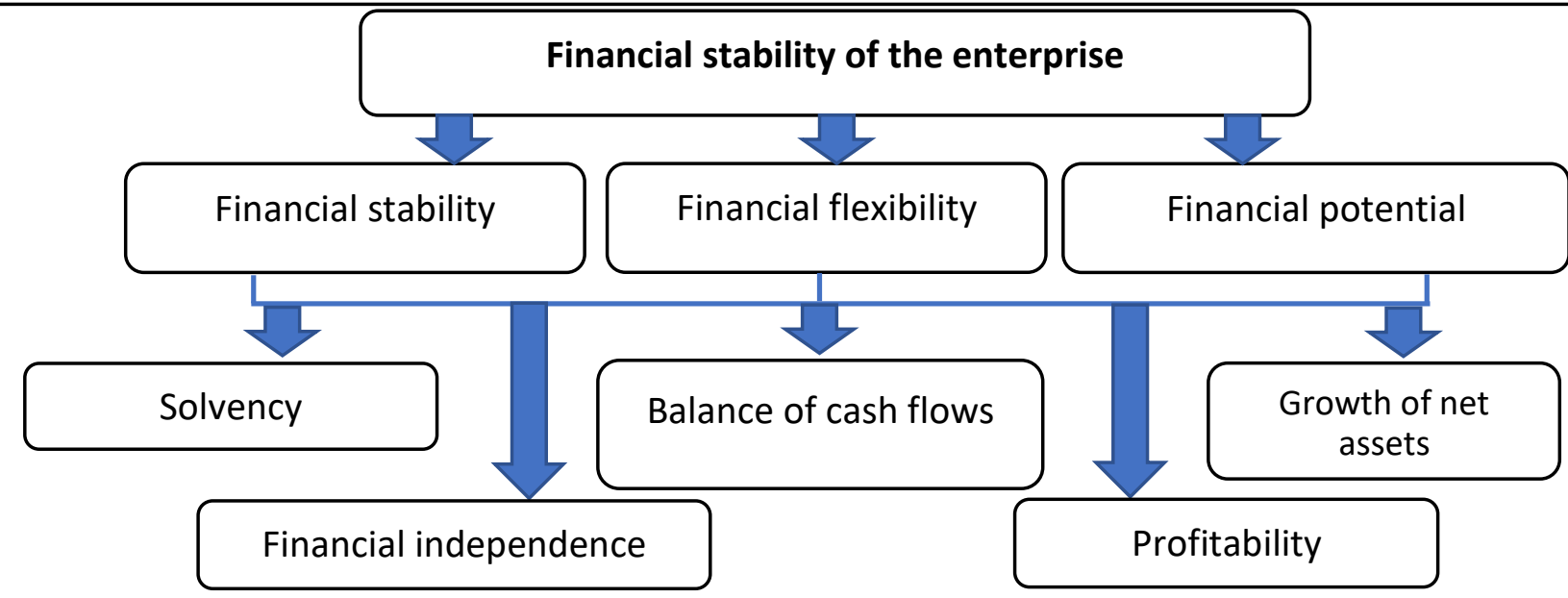

Fig. 1. Model of financial stability of the enterprise

Financial flexibility - the ability of the enterprise to quickly generate the required amount of financial resources in the event of the unexpected emergence of highly effective financial proposals or new opportunities to accelerate economic development. Indicators for determining financial flexibility: high liquidity of assets; asset quality, growth of net assets; duration of the payback period.

The financial potential of the enterprise is a set of existing and potential capabilities of the enterprise to mobilize and increase their volume and transform them into other factors of production in accordance with the needs in order to achieve strategic and tactical goals of the enterprise. That is, the financial potential not only includes financial resources, but also provides for their effective use and mobilization to ensure the capabilities and sustainability of production and other processes in the enterprise.

Under the financial crisis understand the phase of unbalanced activities of the enterprise and the limited possibilities of its impact on financial relations.

In practice, the crisis is usually identified with the threat of insolvency and bankruptcy of the enterprise, its activities in the non-profit zone or lack of available potential for successful operation. The main factors that can cause a financial crisis in the enterprise include: external or exogenous (which do not depend on the activities of the enterprise), and internal or endogenous (which depend on the enterprise). The main exogenous factors of the financial crisis in the enterprise may be: the decline in the economy as a whole; significant inflation; instability of economic and tax legislation; instability of financial and currency markets; increased competition in the industry and the crisis of a particular industry; strengthening market monopoly; discrimination of the enterprise by the authorities and management;

The main endogenous factors of the financial crisis: lack of a clearly defined strategy for enterprise development; deficits in the organizational structure; low level of management; low level of marketing and loss of markets for products; unsatisfactory use of production resources; unproductive maintenance of redundant jobs.

In general, all these causes of the crisis are quite closely interconnected and create a complex set of causal links. Of course, examining a particular company, a particular case of financial crisis, we can identify certain specific causes of financial insolvency, but all of them are usually reduced to those already listed. Typical consequences of the influence of the above reasons and factors on the financial and economic condition of the enterprise are: loss of customers and buyers of finished products; reducing the number of orders and contracts for the sale of products; increase in cost and a sharp decrease in productivity; increase in the amount of illiquid current assets and the presence of 
excess stocks; increasing pressure on prices; a significant reduction in sales and, as a consequence, a shortfall in sales revenue.

There are the following types of crisis:

strategic crisis (when the enterprise has destroyed the production potential and lacks long-term success factors);

profitability crisis (permanent losses "eat" equity, and this leads to an unsatisfactory balance sheet structure);

liquidity crisis (when the company is insolvent or there is a real threat of insolvency).

There are close causal links between these types of crises: a strategic crisis causes a crisis of profitability, which, in turn, leads to illiquidity of the enterprise. An important prerequisite for the application of the right anti-crisis measures is the identification of the depth of the financial crisis. There are three phases of the crisis:

a) one that does not directly threaten the functioning of the enterprise (subject to its transfer to the regime of crisis management);

b) which threatens the continued existence of the enterprise and requires immediate financial rehabilitation;

c) a state of crisis that is incompatible with the continued existence of the enterprise and leads to its liquidation.

Identifying the phase of the financial crisis is a necessary prerequisite for a proper response to it. To prevent a financial crisis, it is necessary to conduct a comprehensive analysis of the financial condition of the enterprise. The availability and sufficiency of economic resources means whether the company is able to emerge from the crisis, taking into account all available material, financial, labor, innovation, information resources. The vector of change means their direction, taking into account the causes (internal and external) of the crisis.

To diagnose the current state and key problems of the enterprise it is important to assess its financial condition. The financial stability of the enterprise is one of the most important characteristics of the financial condition of the enterprise, it is related to the overall financial structure of the enterprise, with the degree of its dependence on creditors and investors. Financial stability characterizes the stability of the enterprise in the long run.

Analysis of financial stability allows us to assess the rationality of the capital structure from the standpoint of maintaining financial independence, solvency and creditworthiness, to identify the limits of change in various sources of funding. Indicators of financial stability are able to show the degree of possible risk of bankruptcy of the enterprise in connection with the use of borrowed financial resources. The crisis or pre-crisis state of enterprises was confirmed by the results of determining the degree of financial stability, to assess which the following indicators were used:

$\pm E c$ - surplus (+) or shortage (-) of working capital to create stocks and compensate for the costs of economic activity of the enterprise;

$\pm E m$ - surplus (+) or shortage (-) of own working capital (funds), medium- and long-term loans and borrowings;

$\pm E H$ - surplus (+) or deficit (-) of total working capital.

These indicators correspond to the indicators of the provision of stocks and costs by the sources of their formation. They are calculated by the following formulas:

$$
\begin{gathered}
\pm E_{c}=E_{c}-Z, \\
\pm E_{m}=\left(E_{c}+K_{m}\right)-Z, \\
\pm E_{H}=\left(E_{c}+K_{m}+K_{t}\right)-Z,
\end{gathered}
$$

where $Z$ - sum of stocks and costs;

$E_{c}$ - the amount of own working capital of the enterprise;

$E_{m}$ - the amount of own current and long-term debt sources;

$E_{n}$ - the total value of the main sources of stock formation

$K_{m}$ - medium-term and long-term loans and borrowings;

$K_{t}$-short-term loans and borrowings.

Depending on the values of the evaluation indicators, 5 spheres of financial stability (or spheres of risk) are removed. They can be compared with five levels of financial security: absolute, normal, unstable, critical and crisis security.

Absolute financial stability and absolute security correspond to the case when the company's activities provide its own working 
capital:

$$
\pm E_{c} \geq 0, \pm E_{m} \geq 0, \pm E_{H} \geq 0,
$$

Normal financial stability and normal security are diagnosed when the company provides its own sources of inventory formation and cost recovery:

$$
\pm E_{c} \approx 0, \pm E_{m} \approx 0, \pm E_{H} \approx 0,
$$

Unstable financial condition and security level is diagnosed for the case, when the company does not have enough working capital, and it is close to the need for medium-term and long-term loans and credits:

$$
\pm \mathrm{E}_{\mathrm{c}} \prec 0, \pm \mathrm{E}_{\mathrm{T}} \geq 0, \pm \mathrm{E}_{\mathrm{H}} \geq 0,
$$

Critical financial condition and a critical level of security are diagnosed for the case, when the company to finance its activities is approaching a constant need for short-term loans:

$$
\pm \mathrm{E}_{\mathrm{c}} \prec 0, \pm \mathrm{E}_{\mathrm{T}} \prec 0, \pm \mathrm{E}_{\mathrm{H}} \geq 0,
$$

Crisis and crisis level of security is diagnosed for the case when the enterprise does not provide financing of the activity by any means, approaching bankruptcy:

$$
\pm \mathrm{E}_{\mathrm{c}} \prec 0, \pm \mathrm{E}_{\mathrm{T}} \prec 0, \pm \mathrm{E}_{\mathrm{H}} \prec 0,
$$

Table 1 presents a rapid analysis, which provides for the calculation of indicators that

\begin{tabular}{|c|c|c|c|c|c|}
\hline \multirow[b]{2}{*}{ Indicators } & \multirow[b]{2}{*}{2015} & \multirow[b]{2}{*}{2016} & \multirow[b]{2}{*}{2017} & \multicolumn{2}{|c|}{ Absolute deviation,,+-} \\
\hline & & & & $\begin{array}{c}2016 \text { to } \\
2015 \\
\end{array}$ & $\begin{array}{c}2017 \text { to } \\
2016\end{array}$ \\
\hline The share of fixed assets in assets & 0.22 & 0.15 & 0.12 & -0.08 & -0.03 \\
\hline Depreciation rate of fixed assets & 0.87 & 0.85 & 0.87 & -0.01 & 0.02 \\
\hline $\begin{array}{l}\text { Asset turnover (turnover), resource efficiency, } \\
\text { transformation ratio }\end{array}$ & 1.91 & 2.23 & 2.13 & 0.32 & -0.09 \\
\hline Return on assets & 8.83 & 12.87 & 16.18 & 4.03 & 3.31 \\
\hline Inventory turnover ratio (turnover) & 7.19 & 4.27 & 4.38 & -2.91 & 0.1 \\
\hline Receivables turnover ratio (turnover) & 11.33 & 6.3 & 5.42 & -5.03 & -0.89 \\
\hline Return on assets by net income, $\%$ & -23.32 & 9.95 & 3.44 & 0.33 & -0.07 \\
\hline Payback period of equity & 1.84 & -3.25 & -5.57 & -5.09 & -2.32 \\
\hline Coefficient of providing own working capital of stocks & -1.76 & -0.83 & -0.7 & -0.93 & 0.13 \\
\hline Coefficient of financial independence (autonomy) & -0.51 & -0.22 & -0.17 & 0.29 & 0.05 \\
\hline Coefficient of financial stability & -0.51 & -0.22 & -0.16 & 0.29 & 0.05 \\
\hline Current ratio (coverage) & 0.51 & 0.69 & 0.75 & 0.18 & 0.06 \\
\hline Absolute liquidity ratio & 0.02 & 0 & 0 & -0.01 & 0 \\
\hline The ratio of short-term receivables and payables & 0.58 & 0.49 & 0.54 & -0.09 & 0.05 \\
\hline
\end{tabular}
indicate the various areas of financial activity of the enterprise - liquidity, stability, profitability, business activity and more.

Table 1 - Express analysis of the financial condition of PJSC "Odesavinprom"

The analysis shows that the share of fixed assets in assets, investment in fixed assets is declining. That is, in terms of increasing income, the share of fixed assets decreases, which indicates the optimization of the structure of fixed assets.

The value of asset turnover increases, i.e. the efficiency of use of all assets increases. Partly in 2017, the company reduces the efficiency of use of assets, which is associated with a decrease in production activity.

The rate of return on assets indicates that the efficiency of use of fixed assets for the period under study increased and for every hryvnia of fixed assets involved in the operating process, the company in 2017 produced products and provided services in the amount of $16.18 \mathrm{UAH}$.

The turnover ratio of inventories is declining. If the ratio significantly exceeds the industry average, it creates a risk associated with insufficient inventories, which will result in a decrease in sales revenue. Too high a ratio can be a sign of lack of free funds and a signal of possible insolvency of the enterprise. The normal value of the ratio can range for different areas of business from 4 to 8 . In 2016, the value of the indicator 
decreases by - 2.91 compared to the previous year. This indicates a decrease in the efficiency of inventory management and may be a sign of reduced sales activity. In 2017, the trend is changing and there is an increase in the efficiency of inventory use. In 2017, they made 4.38 revolutions. The turnover of receivables indicates a decrease in the efficiency of receivables management. In 2017, the trend remained unchanged and at the end of the study period receivables amounted to 5.42 turnovers.

Return on assets in 2015 amounted to $-23.32 \%$, ie for each hryvnia of assets the company received -23.32 kopecks of net loss. In $2016-9.95$ kopecks of net profit. In 2017, the value of the return on assets was $3.44 \%$.

The company has a negative value of the amount of working capital, which does not allow to finance stocks at its own expense. To do this, the company attracts borrowed resources. The level of financial risks is high, because the coefficient of autonomy is negative. In 2016, the value of the indicator was lower than the norm. At the end of the study period, the value of the indicator was -0.17 .

The coefficient of financial stability takes into account not only equity but also long-term liabilities and characterizes the level of financial stability in the long run for more than 1 year. In $2015,-51.07 \%$ of assets were financed from permanent or long-term sources of financing. The normative value is 0.8 and more. In 2016, the value of the indicator was -0.22 , i.e. the company financed its assets by $-21.6 \%$ due to stable sources of capital formation. This value is below the norm.

The value of the liquidity ratio is below the norm, ie the company is not able to repay all its obligations during the year. In 2016, each hryvnia of current liabilities accounts for UAH 0.69. current assets. In 2017, liquidity was low and UAH 0.75 per UAH of current liabilities. current assets. There are doubts about the company's ability to repay its obligations in a timely manner.

Since the value of the ratio of receivables and payables is less than one, it means that the company receives more financial resources in the form of accounts payable (including trade credits) than directs to the formation of receivables (including trade credits). In 2016, the value of the indicator was 0.49 . In 2017, the policy of accounts payable management was effective, as for every hryvnia of accounts payable there is 0.54 hryvnia of receivables.

The amount of fixed capital decreased in 2016 by $-26.54 \%$. This is a negative trend, which indicates a decrease in the financial stability of the enterprise, because it reduces the amount of capital that will be available to the enterprise, regardless of the conditions in the financial market. In the last period the amount of fixed capital continues to decrease - by $-15.6 \%$, as compared to the previous year. The company has no fixed capital, which indicates a high vulnerability to financial risks. At the end of 2017, the amount of fixed capital of the enterprise amounted to -54809 thousand UAH. The amount of mobile liabilities is constantly growing, which negatively affects current liquidity.

The general financial condition of the enterprise is critical and therefore there is a need to determine the financial stability of the enterprise. Indicators of financial stability (Table 2) are able to show the degree of possible risk of bankruptcy of the enterprise in connection with the use of borrowed financial resources.

The availability of working capital allows the company to pursue a flexible financial policy. The need for borrowed funds, including shortterm ones, is also decreasing, which has a positive effect on financial stability. In 2015, the value of the indicator was negative and the company did not have its own working capital. In 2016 - it is -113163 thousand UAH. At the end of the period we see an increase in the value of the indicator - to -94417 thousand $\mathrm{UAH}$.

In 2015, own financial resources were not used to finance working capital. To do this, the company had to form liabilities. In 2016, the value of the indicator is below the norm, in 2017, own financial resources were used to finance non-current assets, and own working capital was not formed. The maneuverability of own working capital indicates the share of absolutely liquid assets in own working capital, which provide freedom of financial maneuver. Due to the lack of working capital, the indicator for the study period is negative.

The indicator of inventory coverage indicates 
how much per unit of funds invested in inventories, there is a set of working capital, long - and short-term liabilities. A value below 1 indicates a lack of funds for the formation of stocks. Financial resources were insufficient to finance stocks, ie the company cannot ensure the continuity of sales and production process.

Table 2 - Dynamics of financial stability indicators PJSC "Odesavinprom"

\begin{tabular}{|c|c|c|c|c|c|c|c|}
\hline \multirow{2}{*}{ Indicators } & \multirow{2}{*}{2015} & \multirow{2}{*}{2016} & \multirow{2}{*}{2017} & \multicolumn{2}{|c|}{$\begin{array}{c}\text { Absolute deviation, } \\
+,-\end{array}$} & \multicolumn{2}{|c|}{ Relative deviation, $\%$} \\
\hline & & & & $\begin{array}{l}2016 \text { to } \\
2015\end{array}$ & $\begin{array}{l}2017 \text { to } \\
2016\end{array}$ & $\begin{array}{l}2016 \text { to } \\
2015\end{array}$ & $\begin{array}{l}2017 \text { to } \\
2016\end{array}$ \\
\hline Own working capital & -128951 & -113163 & -94417 & 15788 & 18746 & -12.24 & -16.57 \\
\hline $\begin{array}{l}\text { Ratio of current assets with } \\
\text { own funds }\end{array}$ & -0.97 & -0.45 & -0.33 & 0.53 & 0.12 & -54.05 & -26.3 \\
\hline $\begin{array}{l}\text { Maneuverability of working } \\
\text { capital }\end{array}$ & -0.57 & -1.2 & -1.44 & -0.63 & -0.23 & 111.47 & 19.39 \\
\hline $\begin{array}{l}\text { Maneuverability of own } \\
\text { working capital }\end{array}$ & -0.03 & -0.01 & -0.02 & 0.02 & -0 & -62.24 & 34.85 \\
\hline $\begin{array}{l}\text { Coefficient of providing own } \\
\text { working capital of stocks }\end{array}$ & -1.76 & -0.83 & -0.7 & -0.93 & 0.13 & 52.71 & -16.24 \\
\hline Inventory coverage ratio & 0.48 & 1.24 & 1.59 & 0.75 & 0.35 & 154.93 & 28.64 \\
\hline $\begin{array}{l}\text { Coefficient of financial } \\
\text { independence (autonomy) }\end{array}$ & -0.51 & -0.22 & -0.17 & 0.29 & 0.05 & -57.7 & -21.77 \\
\hline $\begin{array}{l}\text { Coefficient of financial } \\
\text { dependence }\end{array}$ & -1.96 & -4.63 & -5.92 & -2.67 & -1.29 & 136.42 & 27.83 \\
\hline Equity maneuverability ratio & 1.46 & 1.74 & 1.72 & 0.28 & -0.02 & 19.46 & -1.14 \\
\hline $\begin{array}{l}\text { Debt capital concentration } \\
\text { ratio }\end{array}$ & 1.51 & 1.22 & 1.17 & -0.29 & -0.05 & -19.51 & -3.87 \\
\hline $\begin{array}{l}\text { Financial stability ratio } \\
\text { (financing ratio) }\end{array}$ & -0.34 & -0.18 & -0.14 & 0.16 & 0.03 & -47.45 & -18.62 \\
\hline $\begin{array}{l}\text { Coefficient of financial } \\
\text { stability }\end{array}$ & -0.51 & -0.22 & -0.16 & 0.29 & 0.05 & -57.7 & -25.37 \\
\hline
\end{tabular}

The level of financial risks is high, because the coefficient of autonomy is negative. At the end of the study period for each hryvnia of financial resources is $1.17 \mathrm{UAH}$. obligations.

The coefficient of financial stability takes into account not only equity but also long-term liabilities and characterizes the level of financial stability in the long run for more than 1 year. In $2015,-51.07 \%$ of assets were financed from permanent or long-term sources of financing. The normative value is 0.8 and more. This value is below the norm.

Table 3 identifies the type of financial stability of the enterprise.

Table 3 - Type of financial stability of PJSC "Odesavinprom", thousand UAH

\begin{tabular}{|l|c|c|c|}
\hline \multicolumn{1}{|c|}{ Indicators } & 2015 & 2016 & 2017 \\
\hline Sources of own funds & -88402 & -64940 & -54809 \\
\hline Non-current assets & 40549 & 48223 & 42126 \\
\hline Availability of working capital (row. 1 - row. 2) & -128951 & -113163 & -96935 \\
\hline Long-term loans and borrowings (long-term liabilities) & 0 & 0 & 2518 \\
\hline $\begin{array}{l}\text { Availability of own and long-term borrowed funds for } \\
\text { the formation of stocks and costs (row 3 + row 4) }\end{array}$ & -128951 & -113163 & -94417 \\
\hline Short-term loans and borrowings (current liabilities) & 261489 & 365551 & 376615 \\
\hline The total amount of the main sources of funds for the & 132538 & 252388 & 282198 \\
\hline
\end{tabular}




\begin{tabular}{|l|c|c|c|}
\hline \hline \multicolumn{1}{|c|}{ Indicators } & 2015 & 2016 & 2017 \\
\hline formation of stocks (row. 5 + row. 6) & & & 135744 \\
\hline The total amount of stocks & 73429 & 136269 & -232679 \\
\hline Excess (+), lack (-) of working capital (row 3 - row 8) & -202380 & -249432 & -230161 \\
\hline $\begin{array}{l}\text { Surplus (+), lack (-) of working capital and long-term } \\
\text { borrowings for the formation of stocks (row. 5 - row. 8) }\end{array}$ & -202380 & -249432 & 146454 \\
\hline $\begin{array}{l}\text { Excess (+), lack (-) of the total value of the main sources } \\
\text { of funds for the formation of stocks (row 7 - row 8) }\end{array}$ & 59109 & 116119 & $\begin{array}{c}\text { Problem } \\
\text { condition }\end{array}$ \\
\hline Type of financial stability & $\begin{array}{c}\text { Problem } \\
\text { condition }\end{array}$ & $\begin{array}{c}\text { Problem } \\
\text { condition }\end{array}$ & \\
\hline
\end{tabular}

As can be seen from the calculations, during the study period, the company lacks its own working capital and long-term borrowed funds for the formation of stocks. This creates risks of financial stability, because in the case of limited short-term debt sources of financing, the company will not be able to create reserves of raw materials, goods and materials for smooth operation. Therefore, the type of financial stability - a problematic situation. The researched enterprise was in a state of crisis, ie it catastrophically lacked sources of financing. Since working capital has a negative value, it can be argued that the company has its own funds to invest in current (liquid) assets are not enough or they are absent and the company operates on short-term liabilities.

Taking into account all these factors, it is advisable to assess the likelihood of bankruptcy. For calculation we will use Altman's five-factor model:

$$
Z=1,2 \cdot X_{1}+1,4 \cdot X_{2}+3,3 \cdot X_{3}+0,6 \cdot X_{4}+X_{5},(9)
$$

where $\mathrm{X}_{1}$ - working capital to the sum of the assets of the enterprise. The indicator estimates the amount of net liquid assets of the enterprise in relation to total assets;

$\mathrm{X}_{2}$ - retained earnings to the amount of assets of the enterprise, reflects the level of financial leverage of the enterprise;

$\mathrm{X}_{3}$ - pre-tax profit to total assets. The indicator reflects the efficiency of operating activities of the enterprise;

$\mathrm{X}_{4}-$ market value of equity / book (book) value of all liabilities;

$X_{5}$ - sales to total assets of the enterprise characterizes the return on assets of the enterprise.

As a result of calculation of $\mathrm{Z}$ - indicator for the concrete enterprise the conclusion becomes:

If $Z<1.81$ - the probability of bankruptcy is from 80 to $100 \%$;

If $Z=1.81-2.77$ - the average probability of failure of the company from 35 to $50 \%$;

If $Z=2.77-2.99-$ the probability of bankruptcy is not high from 15 to $20 \%$;

If $Z>2.99$ - the situation at the enterprise is stable, the risk of insolvency in the next two years is negligible.

The accuracy of the forecast in this model on the horizon of one year is $95 \%$, for two years $-83 \%$. The calculations are presented in table 4.

Table 4 - Bankruptcy probability forecasting PJSC "Odesavinprom"

\begin{tabular}{|l|c|c|c|}
\hline \multicolumn{1}{|c|}{ Indicators } & 2015 & 2016 & 2017 \\
\hline Working capital to the amount of assets of the enterprise & -0.75 & -0.38 & -0.29 \\
\hline The ratio of net income to total assets & -0.23 & 0.1 & 0.03 \\
\hline The ratio of profit to taxes to the amount of assets & -0.23 & 0.08 & 0.03 \\
\hline The ratio of equity to debt (financial structure) & -0.34 & -0.18 & -0.14 \\
\hline The ratio of sales revenue to the amount of assets (asset turnover) & 1.91 & 2.23 & 2.13 \\
\hline \multicolumn{1}{|c|}{$\mathbf{Z}=$} & $\mathbf{1 . 0 3}$ & $\mathbf{1 . 9 6}$ & $\mathbf{1 . 8 8}$ \\
\hline
\end{tabular}

During the study period, the company had a very high and medium probability of bankruptcy- from 35 to $50 \%$. In general, it is connected with a complex of the problems connected both with 
factors of the internal environment of the enterprise, and with the considerable dynamic changes occurring in external environment. PJSC "Odesavinprom" prefers to use the borrowed funds, while quite effectively manages them.

Thus, currently companies face such problems as low liquidity and solvency, lack of working capital and own funds, high dependence on borrowed funds.

To develop a model for optimizing the financial stability of the enterprise we use the method of correlation and regression analysis. The correlation represents a probable relationship between indicators that are not functionally dependent. This method is used to determine the closeness of the relationship between indicators of financial stability. To do this, we introduce the following notation: $x_{1}$ coefficient of autonomy; $x_{2}$ - financial risk ratio; $\mathrm{x}_{3}$ - debt ratio; $\mathrm{x}_{4}$ - coefficient of financial stability; $x_{5}$ - coefficient of maneuverability; $x_{6}-$ the ratio of own working capital. We compile an economic model of multiple regression in the form of:

$$
\widehat{y}=a_{0}+b_{1} x_{1}+\cdots+b_{n} x_{n}
$$

The parameter is a free term of the regression equation, i.e. it is a value $x_{n}=0$. If $x_{n}$ does not become zero, this parameter has only a calculated purpose. In the linear equation, the parameters $b_{n}$ are called the regression coefficient. It shows how many units on average the value of the feature will change with the $y$ change (increase) of the value of the feature $x_{n}$ per unit. It has a unit of measurement of the performance trait. In the case of direct communication $b_{1}, \ldots, b_{n}$ the value is positive, and the opposite - negative. Determine the estimates $b_{1}, \ldots, b_{n}$ parameters by the method of least squares. We highlight the main target indicators of financial stability of the studied enterprise, which will be taken into account when building a forecasting model. The necessary initial data are taken from table 5 and calculate the parameters of the regression equation.

Table 5 - Parameters of the regression equation

\begin{tabular}{|c|c|c|c|c|c|c|c|}
\hline Year & $\begin{array}{c}\text { Coefficient } \\
\text { of } \\
\text { financial } \\
\text { stability }\end{array}$ & $\begin{array}{c}\text { Financial } \\
\text { risk ratio }\end{array}$ & $\begin{array}{c}\text { Debt } \\
\text { ratio }\end{array}$ & $\begin{array}{c}\text { Coefficient } \\
\text { of } \\
\text { autonomy }\end{array}$ & $\begin{array}{c}\text { Coefficient of } \\
\text { maneuverability }\end{array}$ & $\begin{array}{c}\text { Coefficient } \\
\text { of stability } \\
\text { of mobile } \\
\text { means }\end{array}$ & $\begin{array}{c}\text { Defense } \\
\text { capital } \\
\text { provision } \\
\text { ratio }\end{array}$ \\
\hline & $y$ & $x_{1}$ & $x_{2}$ & $x_{3}$ & $x_{4}$ & $x_{5}$ & $x_{6}$ \\
\hline 2011 & 0,812 & 0,404 & 0,287 & 0,714 & $-0,032$ & 0,071 & $-0,087$ \\
\hline 2012 & 0,322 & 0,671 & 2,013 & 0,012 & 0,502 & 0,408 & 0,321 \\
\hline 2013 & 0.463 & 0,070 & 2,412 & 0,124 & 2,690 & 0,523 & 0,302 \\
\hline 2014 & -0.122 & $-1,960$ & 2,312 & $-0,340$ & 1,120 & 0,641 & 0,247 \\
\hline 2015 & -0.510 & $-2,92$ & 2,418 & -0.510 & 1,460 & 0,608 & 0,330 \\
\hline 2016 & -0.220 & $-4,63$ & 2,178 & -0.220 & 0,536 & 0,413 & 0,314 \\
\hline 2017 & -0.160 & $-5,92$ & 2,123 & -0.170 & 1,128 & 0,556 & 0,317 \\
\hline
\end{tabular}

We make an economic model according to table 5 . We have a system of multifactor models:

$$
\left\{\begin{array}{c}
y=a_{0}+b_{1} x_{2} \\
x_{2}=a_{0}+b_{1} x_{1}+b_{2} x_{6} \\
x_{1}=a_{0}+b_{1} x_{3} \\
x_{6}=a_{0}+b_{1} x_{4}+b_{2} x_{5}
\end{array}\right.
$$

The regression equation looks like this:

$$
\widehat{y}=0,806-0,187 x_{2}
$$

Table 6 shows the forecast of financial stability of the enterprise through the coefficient of financial stability. 
Table 6 - Predictive values of the coefficient of financial stability of the enterprise

\begin{tabular}{|c|c|c|cc|}
\hline Factor & Year & Forecast & \multicolumn{2}{|c|}{ Characteristics of the equation } \\
\hline \multirow{4}{*}{$\begin{array}{c}\text { Coefficient of } \\
\text { financial } \\
\text { stability }\end{array}$} & 2018 & $-0,021$ & $R^{2}=0,7255$ & $F_{r}=15,0321$ \\
\cline { 2 - 3 } & 2019 & $-0,007$ & $S_{y}=0,4527$ & $F_{t}=5,3200$ \\
\cline { 2 - 3 } & 2020 & $-0,112$ & \multirow{2}{*}{$t_{k r}=99$} & $t_{0}=8,1039$ \\
& 2021 & $-0,104$ & & $t_{1}=3,7721$ \\
\hline
\end{tabular}

Equation $\hat{y}=0,806-0,187 x_{2}$ indicates that the coefficient of financial stability tends to decrease (by units 0.187)

The predicted value of the coefficient of financial stability can be used to develop the financial strategy of the enterprise or corrective anti-crisis management decisions. Figure 2 shows the trend of financial stability of the enterprise.

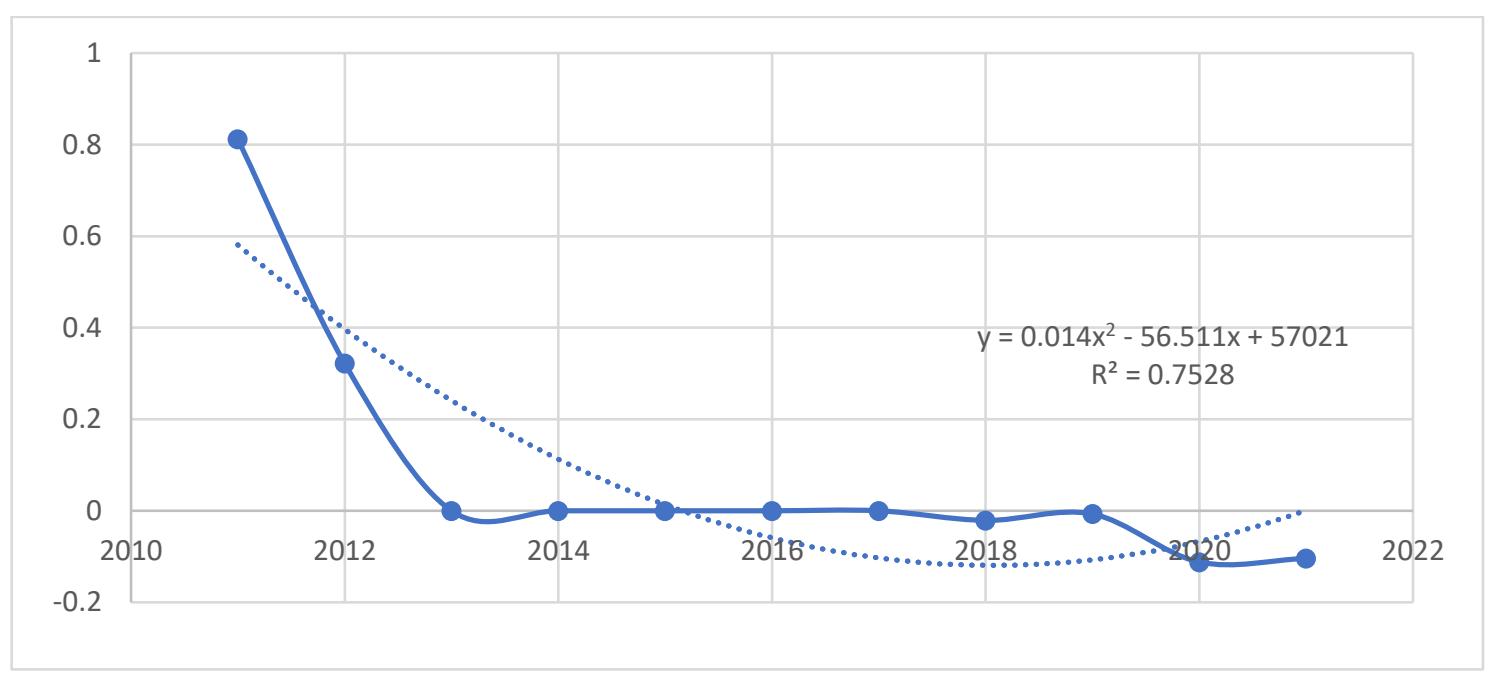

Fig. 2. Trend of financial stability of the enterprise (polynomial trend line)

To study and predict the level of financial stability of the enterprise using trend models, it is advisable to use a polynomial trend line, as this model more accurately shows and compares actual and theoretical values of inflation and has a coefficient of determination $\mathrm{R}^{2}=0.7528$, which indicates the quality of the selected model. If you make a forecast for the next period, this model can be effectively used to analyze this process.

Assessing the potential of financial stability is one of the priority tasks of financial diagnostics of crisis enterprises, the state of which is characterized by an increased probability of bankruptcy. It is important to distinguish between signs that reflect the inability to service debt obligations (insolvency and excessive business risk), and those related to the lack of requirements for the company under the assumptions of liquidation or further continuation of activities (default and unprofitability). If it is found that the crisis enterprise consistently demonstrates insolvency and excessive business risk, it is logical to state the lack of rehabilitation potential and, consequently, the inexpediency of crisis management.

The financial stability of the enterprise is a form of maintaining financial balance at a certain point in time. At the stage of positive dynamic financial 
equilibrium there is an active financing of own development, including and innovation. Thanks to the latter, based on the action of positive feedback, it is possible to achieve a qualitatively new financial equilibrium - a state with enriched resource potential. The positive financial balance of the enterprise can be disturbed by the influence of bifurcations, which create a certain uncertainty of the prospects for the development of its activities. However, due to the passage of the bifurcation stage for the company it becomes possible to reduce the path to achieve a qualitatively new financial balance. At the same time, the bifurcation financial condition of the enterprise hides the threat of early signs of financial crisis. To prevent the development of the scenario of financial imbalance in the company should be activated protective mechanisms of its financial security, based on the actions of not only negative but also positive feedback. The latter has the ability to direct the use of the accumulated financial potential of the enterprise in the direction of positive changes in its activities and achieve a qualitatively higher level of financial equilibrium. In the case of a pessimistic scenario of exit from the bifurcation stage, the company develops a negative dynamic financial equilibrium, which takes the form of a financial crisis. The company's entry into the crisis phase is most likely due to the lack of adequate financial security measures in the bifurcation period. based on the actions of not only negative but also positive feedback. The latter has the ability to direct the use of the accumulated financial potential of the enterprise in the direction of positive changes in its activities and achieve a qualitatively higher level of financial equilibrium. In the case of a pessimistic scenario of exit from the bifurcation stage, the company develops a negative dynamic financial equilibrium, which takes the form of a financial crisis. The company's entry into the crisis phase is most likely due to the lack of adequate financial security measures in the bifurcation period. based on the actions of not only negative but also positive feedback. The latter has the ability to direct the use of the accumulated financial potential of the enterprise in the direction of positive changes in its activities and achieve a qualitatively higher level of financial equilibrium.
In the case of a pessimistic scenario of exit from the bifurcation stage, the company develops a negative dynamic financial equilibrium, which takes the form of a financial crisis. The company's entry into the crisis phase is most likely due to the lack of adequate financial security measures in the bifurcation period. The latter has the ability to direct the use of the accumulated financial potential of the enterprise in the direction of positive changes in its activities and achieve a qualitatively higher level of financial equilibrium. In the case of a pessimistic scenario of exit from the bifurcation stage, the company develops a negative dynamic financial equilibrium, which takes the form of a financial crisis. The company's entry into the crisis phase is most likely due to the lack of adequate financial security measures in the bifurcation period. The latter has the ability to direct the use of the accumulated financial potential of the enterprise in the direction of positive changes in its activities and achieve a qualitatively higher level of financial equilibrium. In the case of a pessimistic scenario of exit from the bifurcation stage, the company develops a negative dynamic financial equilibrium, which takes the form of a financial crisis. The company's entry into the crisis phase is most likely due to the lack of adequate financial security measures in the bifurcation period.

Tools and models of managerial influence to ensure the financial stabilization of the enterprise directly depends on a set of destructive factors. It is possible to allocate stages of management of a financial condition of the enterprise, depending on a stage of detection and development of crisis at the enterprise.

At each stage - specific tools of management influences.

During the current (daily) management:

the management system of the main activity is organized in such a way as to respond quickly to external and internal factors;

periodicity of monitoring of indicators of financial condition of the enterprise;

management decisions to correct insignificant deviations are made and implemented by the heads of "Centers of Responsibility" (divisions of the enterprise);

systemic set of preventive measures to 
counteract the destructive factors of the external and internal environment.

During the period of challenges (dangers):

control of executed decisions is carried out in a regular mode;

management is carried out by the method of accounting for "weak signals", with adequate management response to emerging changes in the environment;

in the monitoring mode, "background surveillance" of danger sources is introduced;

a set of measures is being taken to prevent the spread of danger and the transition of crisis phenomena to a more active phase.

During the period of threat localization:

the system of control measures is strengthened (operational monitoring of sources of threats is introduced, operative meetings on development of collective decisions are held, operative reports on the taken measures are heard);

the nature of decision-making is brought to the highest level of enterprise management. The most important and urgent tasks are transferred for deeper and more comprehensive study;

indicators that characterize the threat of bankruptcy are observed with greater frequency, daily monitoring of "indicators of crisis development" is introduced - the current liquidity ratio, turnover ratio;

an adequate system of measures to prevent bankruptcy of the enterprise is formed, determined by the limit values of financial stability indicators.

During the crisis:

management is characterized by a high degree

\section{of uncertainty;}

a comprehensive program of bringing the company out of the crisis in the form of two alternative documents is being developed: a target program of measures to bring the company out of the crisis or an investment project of financial rehabilitation;

strict centralization of management decisions is introduced;

introduced regimes of austerity of financial and material resources aimed at reducing current needs, causing an increase in liabilities;

measures are taken to exclude from the current assets of the illiquid part (bad receivables), the valuation of illiquid stocks of materials, finished products to the level of demand prices with the possibility of their sale;

measures are taken to raise funds to repay current liabilities to restore solvency by collecting receivables, the sale of assets;

with the growth of accounts payable, its restructuring is carried out;

in the absence of opportunities to repay liabilities with current assets, funds are attracted from the reserve, additional, statutory fund.

In the period of crisis attenuation (adaptation):

a set of measures aimed at leveling the negative effects of destructive factors of the external and internal environment;

current control (monitoring) of adaptive results of management decisions is introduced.

In the general case, the algorithm for applying the design approach in crisis management can be represented as follows (Fig. 3).

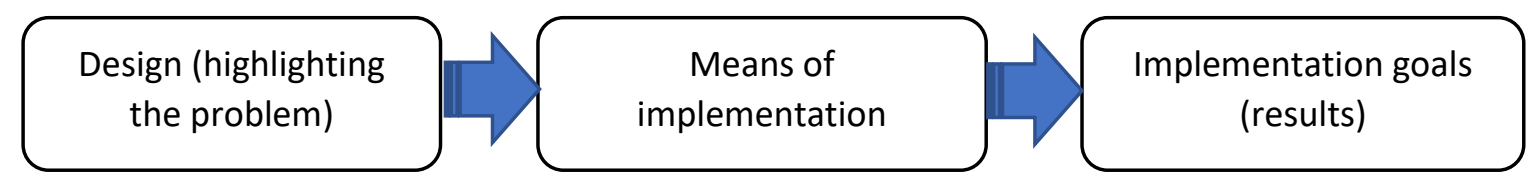

Fig. 3. Algorithm for applying the project approach in crisis management

Project management is the management of important activities in the organization that require constant management in the face of severe restrictions on costs, timing and quality of work. In crisis management, these are the following stages:
Stage 1. Identification of the crisis, determination of the factors of crisis formation and decision-making on the transition to crisis management.

Stage 2. Setting tasks in accordance with the purpose, objectives, methods of implementation, 
appointed managers, executors and controllers of the project. Identify resources to achieve project objectives, including time.

Stage 3. Project implementation:

step-by-step solution of tasks, in accordance with the established terms;

management of the implementation process and control;

intermediate measurement of results, including analysis of enterprise performance indicators.

Stage 4. Completion of the project:

testing of results;

analysis of indicators of financial stability of the enterprise;

decision-making on the transition to operational management.

Thus, the project approach, as a tool for improving the system of crisis management of the enterprise, can be considered from two positions:

creation, implementation and support of projects (programs, portfolios of projects) of the enterprise to ensure sustainable operation in the market or the acquisition of new qualities by the organization or expansion of areas of activity;

implementation of the system of anti-crisis management of the enterprise, ie the organization of management of the organization or any part of it that is in crisis on the basis of the project approach.

It is assumed that this process should consist of two stages: identification of threats and problems of the organization, their assessment, determination of further actions.

The advantages of project management are that project management methods allow: to determine the objectives of the project and to justify it; identify the structure of the project (subgoals, main stages of work to be performed); determine the necessary amounts and sources of funding; select performers; prepare and conclude contracts; determine the terms of the project, schedule its implementation, calculate the necessary resources; calculate the estimate and budget of the project; plan and take into account risks; to ensure control over the progress of the project.

The project approach is characterized by timeliness - i.e. in the period of need for specific decisions and actions. Therefore, the project approach provides an opportunity to approach the tasks of crisis management from the standpoint of "content - cost - time", which is very important for the identification of crisis situations and the formation of specific measures to overcome them.

\section{Conclusions}

Thus, the basis of enterprise management, which is in a crisis situation, is an assessment of the current financial condition, the level of financial stability of the enterprise. To identify trends and causes of changes in financial stability, it is important to factor analysis, which allows you to identify the causes of changes and develop sound recommendations for improving the financial stability of the enterprise. When assessing the probability of bankruptcy, it becomes possible to anticipate options and take measures in advance to increase the financial stability of the enterprise. Improving the financial stability of the enterprise is an important point for overcoming the crisis, which can be associated with both organizational and managerial measures, as well as improving the condition of current assets, resource efficiency. In anti-crisis management of financial stability it is expedient to apply the project approach that will give the chance to implement measures for achievement of the concrete purpose, to coordinate actions of all divisions of the enterprise; to forecast in time and in expenses the project decision of a crisis situation according to the set criteria of quality of performance of works. In addition, the project approach has all the features of a crisis management system: a team of specialists is formed to perform the tasks of crisis management; strategies for increasing the competitiveness of the enterprise are developed; optimal ways (options) of realization of system of anti-crisis measures for the purpose of increase of stability of functioning of the enterprise are made. The advantages of the project approach in anti-crisis management of financial stability are: assessment of the current 
state of the enterprise; use of the company's own resources in order to reduce the cost of implementing a system of anti-crisis measures; clear delineation and definition of personal (team) responsibilities and powers; systematic approaches to determining the phenomena and factors of the crisis, as well as to the development and implementation of anti-crisis programs, due to the involvement of specialists and managers of different levels and areas of activity in accordance with the sources of threats; increasing control over the expenditure of funds and resources aimed at anti-crisis measures, the introduction of methods for their more effective use; more effective use of the time factor in the analysis of the situation and the implementation of anti-crisis measures; qualitative increase of the level of systems and methods of internal communications.

Strategic management of financial stability of the enterprise - the direction of further research.

\section{References}

1. Bondarenko S. A., Nizyayeva V. R. (2017). Bases for provision of stable functioning and stable development of the enterprise / Proceedings of the II International Scientific and Practical Conference., November 18, 2017. Warsaw, Poland. Vol. 2. pp. 49-53.

2. Bondarenko S. A. (2018). Anti-crisis management of innovative development of wine-making enterprises // National Security \& Innovation Activities: Methodology, Policy and Practice:collective monograph / edited by Dr. of Economics, Prof. O. Prokopenko, Ph.D in Economics V. Omelyanenko, Ph.D in Technical Sciences, Assoc. Prof. Yu. Ossik.Ruda Śląska : Drukarnia i Studio Graficzne Omnidium.P. 134-146.

3. Burton, R. M., Obel B. (2004). Strategic
Organizational Diagnosis and Design: The Dynamics of Fit, Third Edition, Springer. Kluwer Academic Publishers. P. 451.

4. Herbane, B., Elliott D., Swartz E. (1997). Contingency and continua: achieving excellence through business continuity planning. Business Horizons, № 40 (6). P. 19-25.

5. Mitroff, I. (1994). Crisis Management and Environmentalism: A Natural Fit. California Management Review (Winter 1994). R. 101113.

6. Patterson, B. (1993). Crises impact on reputation management. Public Relation Journal 49:11, November. R. 48.

7. Rostow, W.W. (1960). The Stages of Economic Growth: A Non-Communist Manifesto. NY: Cambridge Univ. Press, $179 \mathrm{p}$. 